\title{
Composite Electrodes With Carbon Supported Ru Nanoparticles For $\mathrm{H}_{2} \mathrm{O}_{2}$ Detection
}

\author{
Valdrin Januzaj, ${ }^{1}$ Vllaznim Mula, ${ }^{1}$ Graziella L. Turdean ${ }^{2, *}$ \\ and Liana Maria Muresan ${ }^{2} *$ \\ ${ }^{1}$ Department of Chemistry, University of Pristina, 10000 Pristina, Kosovo \\ ${ }^{2}$ Department of Chemical Engineering, Babes-Bolyai University, 400028 Cluj-Napoca, Romania \\ * Corresponding author: E-mail: limur@chem.ubbcluj.ro; gturdean@chem.ubbcluj.ro \\ Tel: +40264595872; Fax: +40264590818
}

Received: 26-05-2014

\begin{abstract}
A new carbon paste electrode (CPE) incorporating Ru nanoparticles (RuNP) stabilized on graphite powder was developed for $\mathrm{H}_{2} \mathrm{O}_{2}$ amperometric detection. Cyclic voltammetric measurements, performed in phosphate buffer solutions at different potential scan rates and different potential ranges were carried out in order to evaluate the electrochemical behavior of the CPE-RuNP modified electrodes. From cyclic voltammetry, at $-0.1 \mathrm{~V} v s . \mathrm{Ag} / \mathrm{AgCl}, \mathrm{KCl}_{\text {sat }}$, the relative increase of the $\mathrm{H}_{2} \mathrm{O}_{2}$ reduction current varies in the following order: 28.47\% (CPE) < 94.81\% (CPE-RuNP $\left.(2.5: 1)\right)<$ $118.19 \%$ (CPE-RuNP $(2.5: 3)$ ) $<152.43 \%$ (CPE-RuNP (2.5:2), recommending the new electrodes as a promising sensors for hydrogen peroxide detection.
\end{abstract}

Keywords: Carbon supported Ru nanoparticles, $\mathrm{H}_{2} \mathrm{O}_{2}$ amperometric detection, carbon paste modified electrodes.

\section{Introduction}

Ru-based catalysts are well-known for electrocatalytic performances,${ }^{1}$ especially in reactions such as oxygen evolution. ${ }^{2-4}$ These abilities are exploited in some very important practical applications, the main being water electrolysis. ${ }^{3-5}$

$\mathrm{Ru}$ electrodes have shown affinity also for the oxygen reduction in both acid $^{6}$ and alkaline ${ }^{7}$ electrolytes. The electrocatalytic reduction of oxygen plays a major role in several industrial processes and in corrosion protection. Thus, it was reported that Ru has a beneficial effect on the passivity of duplex stainless steel corrosion in sodium chloride solution ${ }^{8}$ and that additions of up to $3 \%$ wt Ru increased the corrosion resistance of the WC-Co alloys. ${ }^{9}$

Ruthenium oxide composites were reported as efficient catalysts for non-enzymatic glucose oxidation ${ }^{10}$ and for simultaneous determination of ascorbic acid and dopamine. ${ }^{11}$

Considerably fewer reports exist on $\mathrm{H}_{2} \mathrm{O}_{2}$ detection by using Ru or Ru oxide based electrodes. ${ }^{12,13}$ Hydrogen peroxide is an efficient oxidizing agent used in textile industry, cleaning products, food industry and environmental protection ${ }^{14}$ and an essential intermediate product of enzymatic reactions. ${ }^{15}$ Among these, the electrochemical tracking of biological targets by way of enzyme-based $\mathrm{H}_{2} \mathrm{O}_{2}$ detection is of special interest.

For most electrochemical sensors, the detection of $\mathrm{H}_{2} \mathrm{O}_{2}$ was achieved at positive potentials ${ }^{16-17}$ where the results may be affected by the presence of interferences, (e.g., ascorbic and uric acid). Therefore, decreasing the oxidation potential or performing analysis at its reduction potential is essential for effective detection. ${ }^{18}$

In this paper, a novel electrochemical sensor consisting of a carbon paste electrode modified with carbon supported $\mathrm{Ru}$ nanoparticles (RuNP) was developed for $\mathrm{H}_{2} \mathrm{O}_{2}$ amperometric detection. Cyclic voltammetry and amperometry have been used for the investigation of electrochemical properties and electrocatalytic activity of the nanocomposite modified electrode.

\section{Results and Discussions}

\section{1. Physico-chemical Characterization of Ru-graphite Nanoparticles}

TEM measurements were performed to examine the morphology of carbon supported RuNP. Fig. 1 reveals 


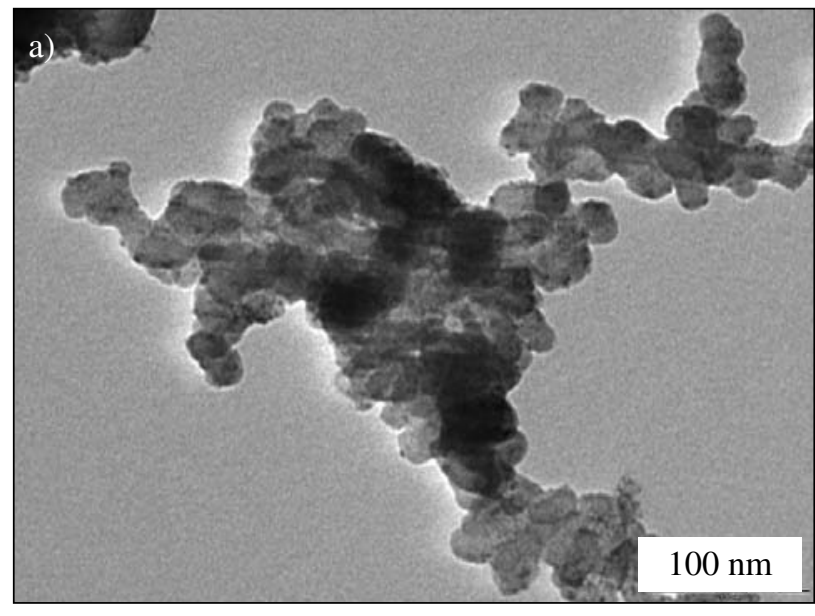

Fig. 1. TEM images of carbon supported RuNP catalyst.

images in which a heterogeneous structure consisting of the carbon substrate (light regions) and the catalyst nanoparticles (dark regions) can be noticed. The carbon supported $\mathrm{Ru}$ nanoparticles are highly dispersed and very small. Nevertheless, agglomerates of different size which are similar in morphology to other Ru-based catalysts reported in the literature ${ }^{3}$ can also be observed.

\section{2. Electrochemical Behavior of the Modified Electrodes}

Cyclic voltammetry (CV) experiments were carried out to investigate the electrochemical behavior of the composite electrode material, in different experimental conditions (variable CPE:RuNP ratios, different potential scan windows) and the results are depicted in Fig. 2A-B.

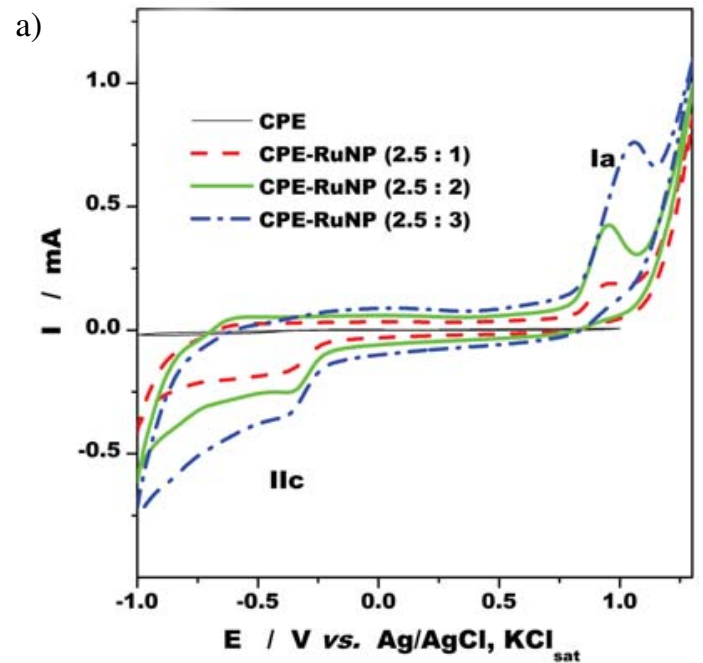

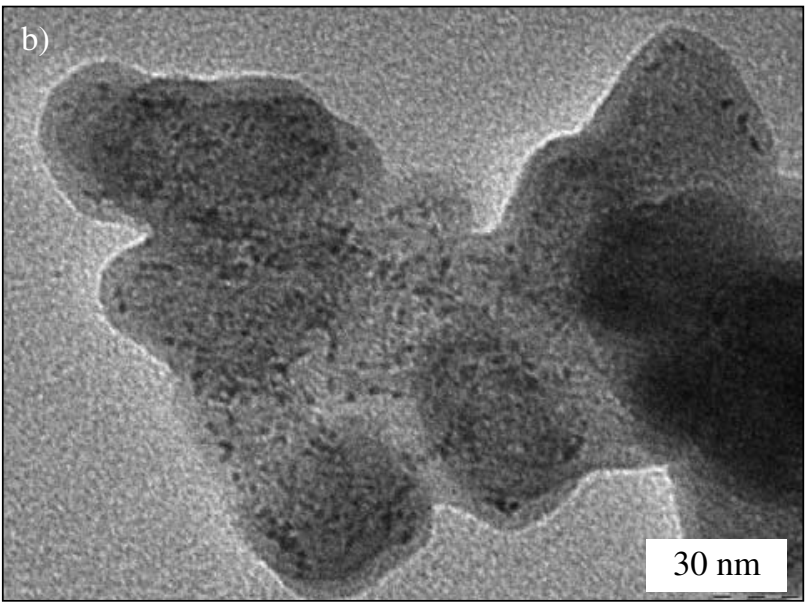

While CV on CPE presents no peaks, in the presence of carbon supported RuNP in the CPE, the CV features (Fig. 2A) exhibit one anodic (Ia) and one cathodic peak (IIc). The anodic peak could be attributed to ruthenium oxidation and the cathodic one, to dissolved oxygen reduction. Previously it was reported that, depending on the potential, ruthenium can be oxidized to hydrated $\mathrm{RuO}^{19}$, $\mathrm{Ru}(\mathrm{OH})_{2}$ or $\mathrm{RuO} \times \mathrm{H}_{2} \mathrm{O}^{20}$, but also to oxides of higher oxidation states $\left(\mathrm{Ru}_{2} \mathrm{O}_{3}\right)$. Moreover, at potentials beyond 1.2 $\mathrm{V}, \mathrm{Ru}$ oxidation to $\mathrm{RuO}_{4}$ overlaps with oxygen evolution. ${ }^{21}$ As expected, the anodic peak intensity increases proportionally with the $\mathrm{Ru}$ amount in the carbon paste. The lack of a peak corresponding to Ru oxides reduction suggests the irreversibility of the formation of these oxides, which are composed of tridimensional aggregates consisting of a structure including various Ru oxides,

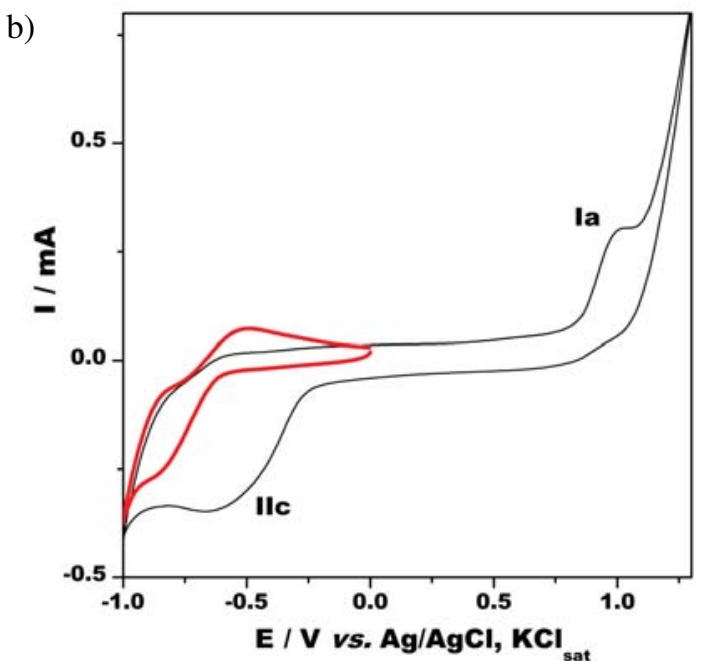

Fig. 2. Cyclic voltammogramms at CPE (thin solid line) and CPE-RuNP modified carbon paste electrodes (a). Influence of the starting potential and scanning domain on the cyclic voltammograms at CPE-RuNP (2.5:1) modified electrode (b). Experimental conditions: electrolyte, 1/15 M phosphate buffer ( $\mathrm{pH} 7$ ); starting potential, $-1 \mathrm{~V}$ vs. $\mathrm{Ag} / \mathrm{AgCl}, \mathrm{KCl}_{\text {sat }}\left(\mathrm{A}, \mathrm{B}\right.$ thin black solid line), $0 \mathrm{~V}$ vs. $\mathrm{Ag} / \mathrm{AgCl}, \mathrm{KCl}{ }_{\text {sat }}(\mathrm{B}$, thick red line); scan rate, $50 \mathrm{mV} / \mathrm{s}$. 

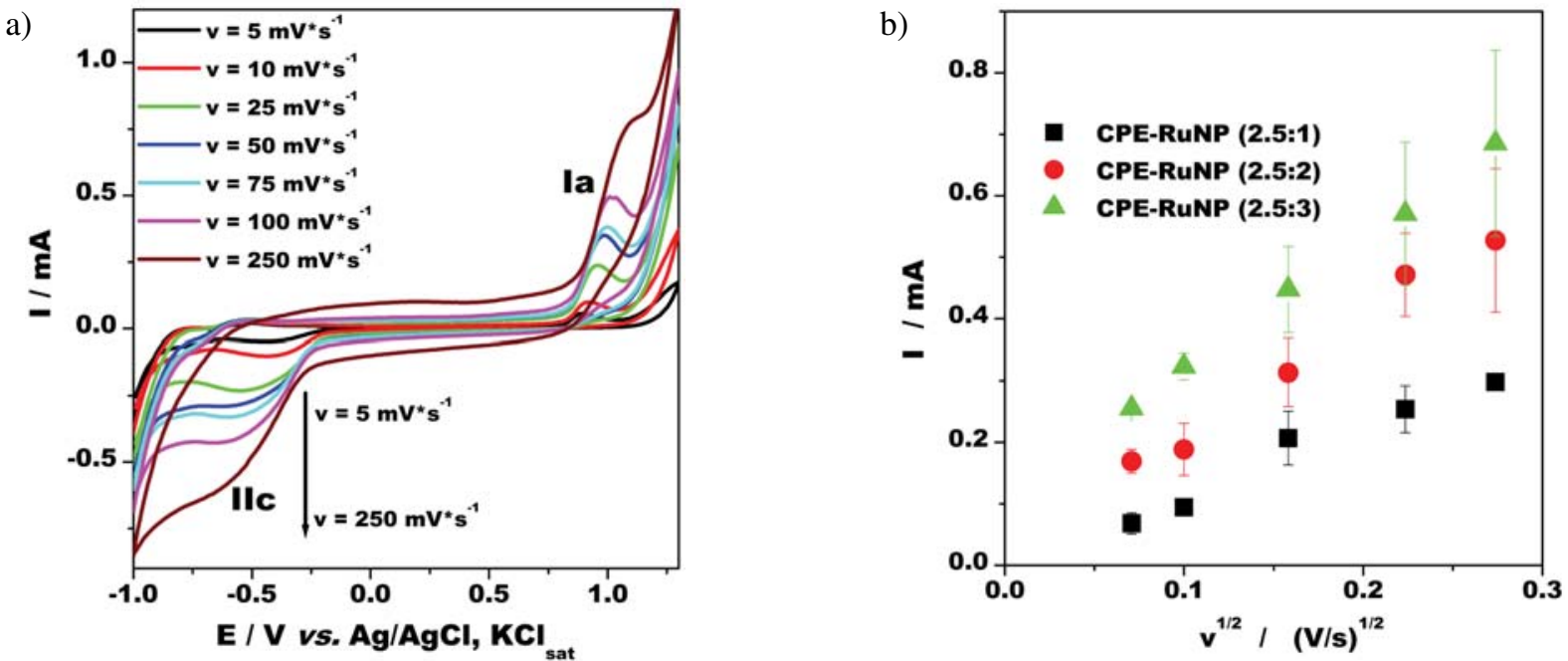

Fig. 3. Influence of the scan rate on the electrochemical response of CPE-RuNP (2.5:1) electrode (a); cathodic current $v s . v^{1 / 2}$ dependence of the process (IIc) occurring at different CPE-RuNP modified electrodes (b). Experimental conditions: see figure 2A, error bar for 4 similar measurements.

bridged oxygen, $\mathrm{OH}$, and water. ${ }^{22}$ These results are confirmed also by other researchers. ${ }^{23}$

It is interesting to note that a potential scan in the negative direction, starting from $0 \mathrm{~V}$, does not reveal any cathodic peak because no Ru oxide (that acts as a catalyst for $\mathrm{O}_{2}$ reduction) is formed during the anodic scan. As can be seen from Fig. 2B, the height of the cathodic peak (IIc) attributed to oxygen reduction is placed at a much more negative value of the potential $(\mathrm{E}=-0.9 \mathrm{~V} v s . \mathrm{Ag} / \mathrm{AgCl}$, $\mathrm{KCl}_{\text {sat }}$ ) than in the case when Ru oxides were formed during the anodic scan $\left(\mathrm{E}=-0.5 \mathrm{~V} v s . \mathrm{Ag} / \mathrm{AgCl}, \mathrm{KCl}_{\text {sat }}\right)$, proving clearly the electrocatalytic properties of $\mathrm{Ru}$ oxides.

As expected for a diffusion-controlled reaction, the current intensity of the oxygen reduction (peak IIc) depends on the potential scan rate in the range $5-250 \mathrm{mV} / \mathrm{s}$ (Fig. 3A), the slope of $\log \mathrm{I}-\log \mathrm{v}$ plot at $-0.5 \mathrm{~V} v \mathrm{~s}$. $\mathrm{Ag} / \mathrm{AgCl}, \mathrm{KCl}_{\text {sat }}$ being $0.500 \pm 0.022$ for CPE-RuNP (2.5:1), $0.456 \pm 0.042$ for CPE-RuNP(2.5:2) and $0.360 \pm$ 0.008 for CPE-RuNP(2.5:3), respectively, with $\mathrm{R}=0.990$, $\mathrm{n}=5$ ). The slope values of the linear dependence of the cathodic current on the square root of the scan rate (Fig. $3 \mathrm{~B})$, close to 0.5 , certify the diffusion control of the oxygen mass transport to the CPE-RuNP electrodes. Also, at high scan rate $(>100 \mathrm{mV} / \mathrm{s})$, a deviation from linearity is observed, indicating that an insufficient solute quantity reaches the electrode surface (results not shown). ${ }^{24}$

As expected, at $\mathrm{pH} 7$, irrespective the potential values (at $-0.1 \mathrm{~V},-0.3 \mathrm{~V}$ and $-0.5 \mathrm{~V}$ vs. $\mathrm{Ag} / \mathrm{AgCl}, \mathrm{KCl}_{\text {sat }}$, respectively), the currents recorded during the cathodic potential scan on CPE-RuNP modified electrodes (peak IIc) increase with the amount of RuNP, respectively with the quantity of $\mathrm{Ru}$ oxides formed during the anodic scan until +1.3 V vs. $\mathrm{Ag} / \mathrm{AgCl}, \mathrm{KCl}_{\text {sat }}$ (Table 1).

Although the current values obtained at $-0.5 \mathrm{~V}$ or $-0.3 \mathrm{~V} v s . \mathrm{Ag} / \mathrm{AgCl}, \mathrm{KCl}_{\text {sat }}$ are greater than those recorded at $-0.1 \mathrm{~V}$ vs. $\mathrm{Ag} / \mathrm{AgCl}, \mathrm{KCl}_{\text {sat }}$, in view to avoid interferences, an applied potential of $-0.1 \mathrm{~V} v s . \mathrm{Ag} / \mathrm{AgCl}, \mathrm{KCl}_{\text {sat }}$ was used for further amperometric measurements of $\mathrm{H}_{2} \mathrm{O}_{2}$ reduction.

\section{3. Electrocatalytic Activity for $\mathrm{H}_{2} \mathrm{O}_{2}$ Reduction}

\subsection{Cyclic Voltammetry}

In order to investigate the electrocatalytic activity of the CPE-RuNP modified electrodes toward $\mathrm{H}_{2} \mathrm{O}_{2}$ reduction, $\mathrm{CVs}$ have been recorded at constant $\mathrm{H}_{2} \mathrm{O}_{2}$ and increa-

Table 1. Cathodic current intensity dependence on the RuNP amounts in the modified electrodes at fixed values of potential. Experimental conditions: see Fig. 2A.

\begin{tabular}{lccc}
\hline Electrode & & $\mathbf{I}_{\mathbf{c}} / \mathbf{A}$ & \\
& $\mathbf{E}_{\mathbf{c}}=\mathbf{- 0 . 1} \mathbf{~ V}$ & $\mathbf{E}_{\mathbf{c}}=\mathbf{- 0 . 3} \mathbf{~ V}$ & $\mathbf{E}_{\mathbf{c}}=\mathbf{- 0 . 5} \mathbf{~ V}$ \\
\hline CPE-RuNP(2.5 : 1)* & $-0.4810^{-4} \pm 0.1910^{-4}$ & $-1.2610^{-4} \pm 0.2210^{-4}$ & $-2.5410^{-4} \pm 0.3810^{-4}$ \\
CPE-RuNP(2.5: 2)* & $-2.0010^{-4} \pm 0.5710^{-4}$ & $-3.1710^{-4} \pm 0.4910^{-4}$ & $-4.7110^{-4} \pm 0.6810^{-4}$ \\
CPE-RuNP(2.5: 3)** & $-2.4510^{-4} \pm 1.2410^{-4}$ & $-3.6910^{-4} \pm 1.1810^{-4}$ & $-5.7110^{-4} \pm 1.1610^{-4}$ \\
\hline
\end{tabular}

where: * values are mean of 4 measurements; ** values are mean of 3 measurements; $\mathrm{E}_{\mathrm{c}}$ is expressed as $\mathrm{V} v$ s. $\mathrm{Ag} / \mathrm{AgCl}, \mathrm{KCl}$ sat 
a)

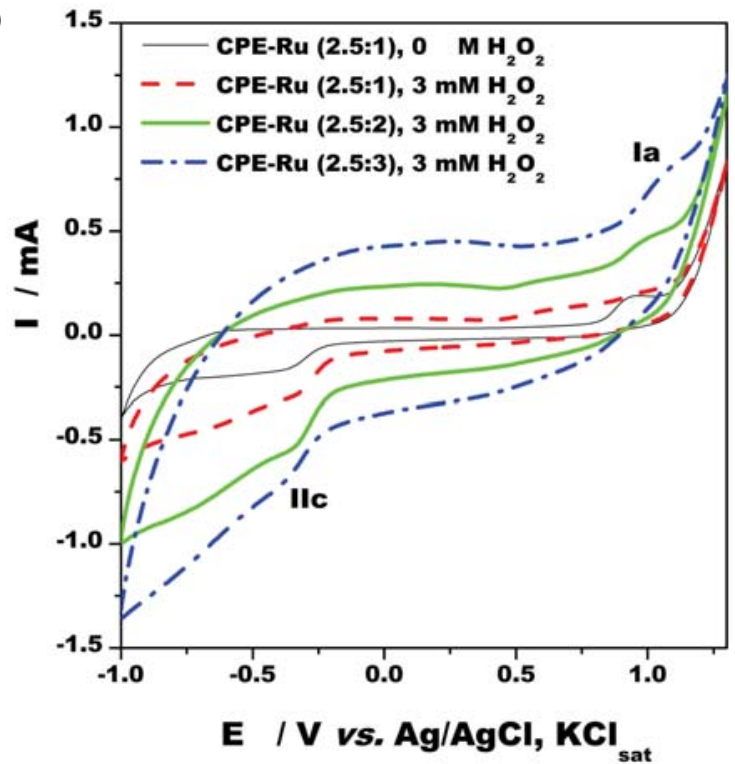

b)

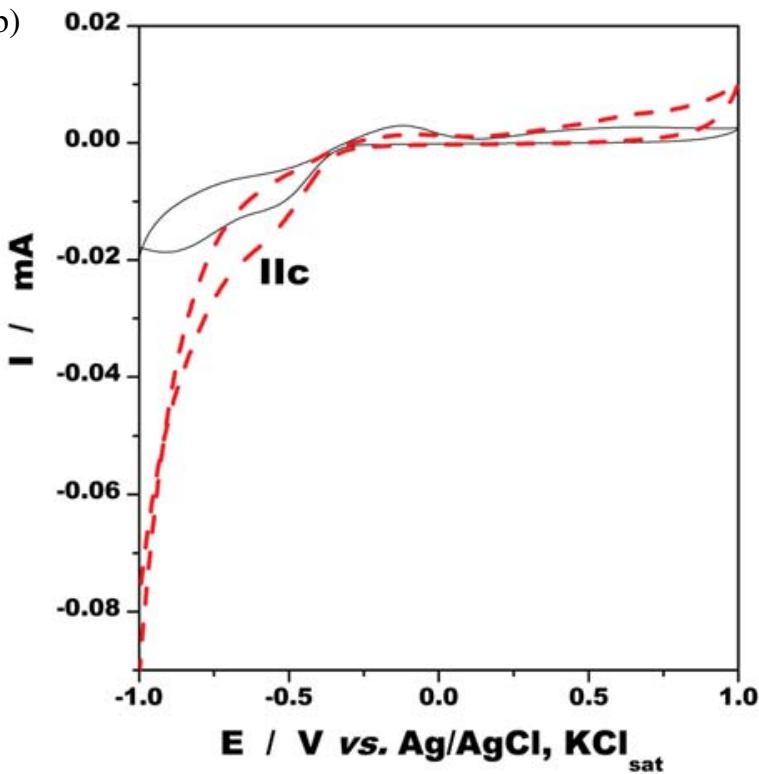

Fig. 4. Electroreduction of $3 \mathrm{mM} \mathrm{H}_{2} \mathrm{O}_{2}$ at CPE-RuNP modified electrode (a) and CPE (b). Experimental conditions: electrolyte, $1 / 15 \mathrm{M}$ phosphate buffer ( $\mathrm{pH} 7$ ) (A, B solid line); starting potential, $-1 \mathrm{~V} v$ s. Ag/ $\mathrm{AgCl}, \mathrm{KCl}_{\text {sat }}$ (A); scan rate, $50 \mathrm{mV} / \mathrm{s}$; graphite:RuNP ratio, see inset legend.

sing RuNP concentration (Fig. 4A) and at unmodified CPE (Fig. 4B) electrodes.

In can be noticed that at concentrations of $3 \mathrm{mM}$ $\mathrm{H}_{2} \mathrm{O}_{2}$, both the anodic and cathodic currents increase with the RuNP amounts present in CPE-RuNP (Fig. 4A).

The influence of the $\mathrm{H}_{2} \mathrm{O}_{2}$ concentrations on the voltammetric currents recorded at $-0.5 \mathrm{~V} v s$. $\mathrm{Ag} / \mathrm{AgCl}, \mathrm{KCl}_{\text {sat }}$ is depicted in Fig. 5A and the corresponding calibration curves in Fig. 5B.

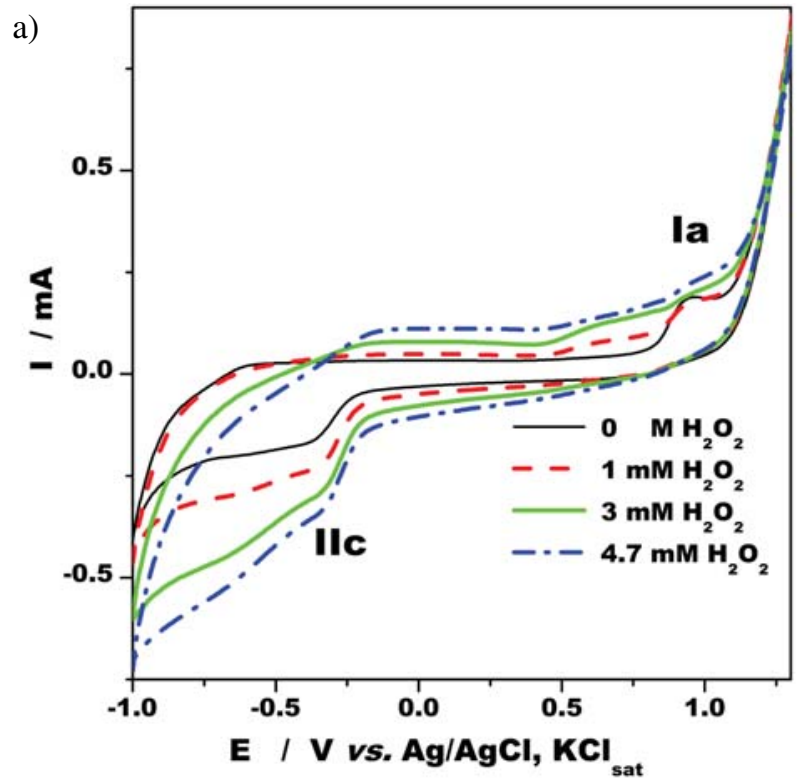

The linear dependence between the currents and $\mathrm{H}_{2} \mathrm{O}_{2}$ concentration allows the determination of the CPERuNP modified electrodes sensitivity (Table 2), which, as expected increase with the amount of RuNP present in the electrode matrix.

The catalytic current, observed in the presence of $\mathrm{H}_{2} \mathrm{O}_{2}$ (Fig. 5A), varied linearly with its concentration in the range between $1-5 \mathrm{mM}$, disregarding the RuNP amount existing in the carbon paste matrix (Fig. 5B). The

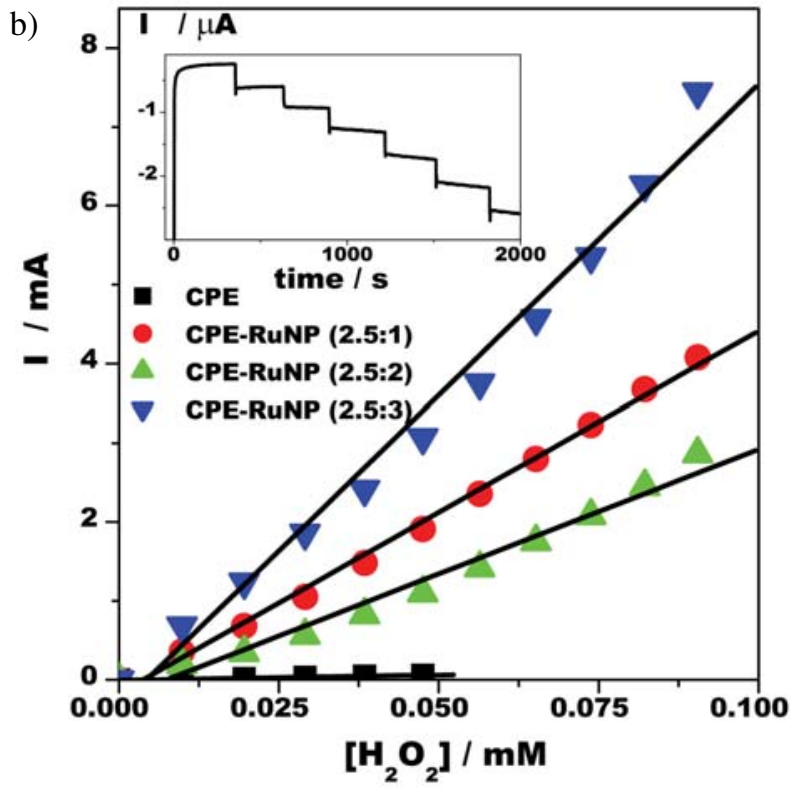

Fig. 5. Cyclic voltammograms at CPE-RuNP (2.5:1) modified electrode at different concentrations of $\mathrm{H}_{2} \mathrm{O}_{2}$ (a). Calibration curve of CPE and CPERuNP modified electrodes (b). Experimental conditions: see Fig. 4. 
relative increase of the $\mathrm{H}_{2} \mathrm{O}_{2}$ reduction current $\left(\mathrm{I}_{\%}\right)$, calculated as $\left(\mathrm{I}-\mathrm{I}_{0}\right) * 100 / \mathrm{I}_{0}$ (where: $\mathrm{I}$ is the current intensity at 3 $\mathrm{mM} \mathrm{H}_{2} \mathrm{O}_{2}$ and $\mathrm{I}_{0}$ is the current in the absence of $\mathrm{H}_{2} \mathrm{O}_{2}$ concentration), increases as follows: $28.47 \%$ (CPE) $<94.81 \%$ (CPE-RuNP $(2.5: 1))<118.19 \%$ (CPE-RuNP $(2.5: 3))<$ $152.43 \%$ (CPE-RuNP (2.5:2)).

\subsection{Amperometry}

Batch amperometric calibration for $\mathrm{H}_{2} \mathrm{O}_{2}$ using the different modified electrodes was performed at a constant potential of $-0.1 \mathrm{~V} v s$. $\mathrm{Ag} / \mathrm{AgCl}, \mathrm{KCl}_{\text {sat }}$. The obtained calibration curves are linear in the range up to $0.1 \mathrm{mM} \mathrm{H}_{2} \mathrm{O}_{2}$ (Fig. 6), with a sensitivity increasing with the amount of RuNP included in the carbon paste matrix (Table 2). The sensitivity of CPE-RuNP(2.5:1) electrode determined by amperometric measurements increases 35 times comparing to the unmodified CPE. The increasing values of the sensitivities observed for both investigation techniques is related to (i) the increase of the electron transfer rate of the $\mathrm{H}_{2} \mathrm{O}_{2}$ to the RuNP, and to (ii) the improved accessibility and reversibility of the electron-transfer process on increasing amounts of RuNP present in the electrode composite matrix. ${ }^{25}$ The linear domain and the sensitivity of the electrodes are in agreement with the values reported in the literature for other $\mathrm{Ru}$ oxide based electrodes for $\mathrm{H}_{2} \mathrm{O}_{2}$ reduction (e.g. $3.5 * 10^{-5} \mathrm{~A} / \mathrm{mM}$ for nano-ruthenium oxide/riboflavin modified glassy carbon). ${ }^{26}$

The response time, estimated as $\mathrm{t}_{95 \%}$, was less than 1 $\mathrm{min}$. The best LOD value (signal/noise ratio of 3 ) is obtained for the CPE-RuNP(2.5:1) electrode which is almost half than in the case of unmodified CPE. For other electrodes having amounts of RuNP approaching or exceeding the amount of graphite, despite the fact that an enhancement of the sensitivity is observed, the LOD value is affected by the increasing values of experimental errors (i.e. $\mathrm{S}_{\mathrm{a}}$ ).

As expected, working in amperometric mode allowed using lower $\mathrm{H}_{2} \mathrm{O}_{2}$ concentrations and the sensors sen-

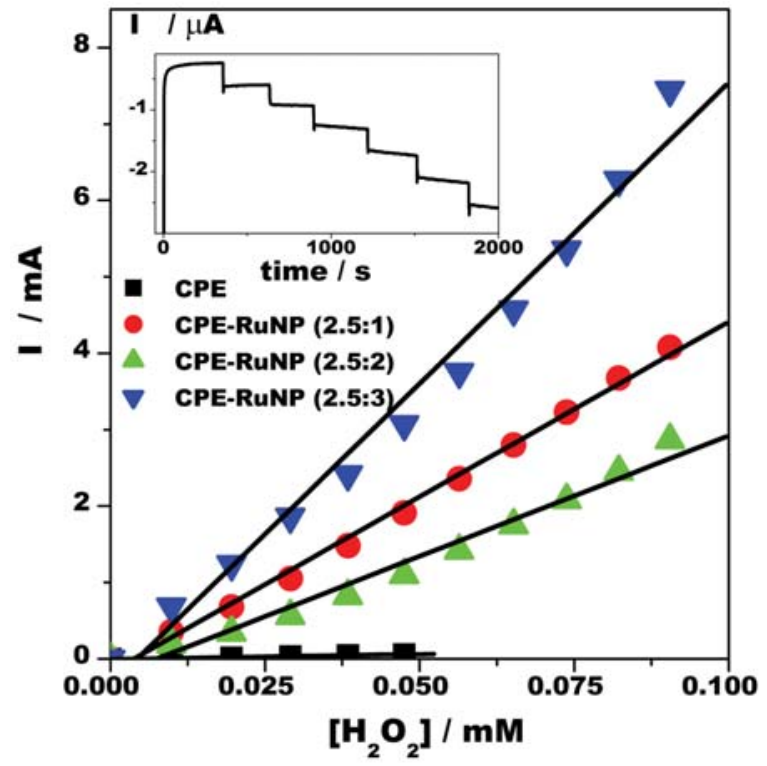

Fig. 6. Calibration curves for $\mathrm{H}_{2} \mathrm{O}_{2}$ electroreduction at CPE and CPE-RuNP modified electrodes. Inset: I vs. time dependence for additions of $0.01 \mathrm{mM} \mathrm{H}_{2} \mathrm{O}_{2}$ at CPE-RuNP (2.5:1) modified electrode. Experimental conditions: electrolyte, $1 / 15 \mathrm{M}$ phosphate buffer ( $\mathrm{pH} 7$ ); applied potential, $-0.1 \mathrm{~V}$ vs. $\mathrm{Ag} / \mathrm{AgCl}, \mathrm{KCl}_{\text {sat }}$; rotation speed, $500 \mathrm{rpm}$.

sitivity estimated from the obtained calibration curves is higher than in cyclic voltammetric method.

\section{Materials and Methods}

\section{1. Materials}

Ru nanoparticles (RuNP) stabilized on carbon powder were prepared by controlled reduction of $\mathrm{RuCl}_{3}$ in polyols followed by slow addition of carbon powder ${ }^{27}$ and were a kind gift from Dr. D. Goia (Clarkson University, USA). For preparing carbon paste electrodes (CPE), graphite powder ( $99.9 \%$ purity) and paraffin oil were purcha-

Table 2. Analytical parameters for CPE-RuNPs modified electrodes. Experimental conditions: see Fig. 6

\begin{tabular}{|c|c|c|c|}
\hline Electrodes & $\begin{array}{l}\text { Cyclic voltammetry } \\
{\left[\mathrm{H}_{2} \mathrm{O}_{2}\right]_{-0.1 \mathrm{~V}} 1 \div 5 \mathrm{mM}} \\
\text { Sensitivity }(\mathrm{A} / \mathrm{mM}) \mathrm{R} / \mathrm{n}\end{array}$ & $\begin{array}{r}\text { Amperometry } \\
{\left[\mathrm{H}_{2} \mathrm{O}_{2}\right]_{-0.1 \mathrm{~V}} \mathrm{0.01} \div \mathrm{0}} \\
\text { Sensitivity }(\mathrm{A} / \mathrm{mM}) \mathrm{R} / \mathrm{n}\end{array}$ & $\begin{array}{l}\mathbf{m M} \\
\mathbf{L O D} * / \mathbf{M}\end{array}$ \\
\hline$\overline{\mathrm{CPE}}$ & $1.210^{-6} \pm 8.310^{-8}$ & $1.310^{-6} \pm 8.110^{-8}$ & \\
\hline & $0.9846 / 4$ & $0.9923 / 6$ & 5.43 \\
\hline CPE-RuNP(2.5:1) & $50.210^{-6} \pm 4.310^{-6}$ & $45.910^{-6} \pm 1.110^{-6}$ & \\
\hline & $0.9640 / 6$ & $0.9976 / 11$ & 3.78 \\
\hline CPE-RuNP(2.5:2) & $107.910^{-6} \pm 9.510^{-6}$ & $31.610^{-6} \pm 1.710^{-6}$ & \\
\hline & $0.9626 / 6$ & $0.9878 / 11$ & 8.62 \\
\hline CPE-RuNP(2.5:3) & $123.810^{-6} \pm 10.910^{-6}$ & $78.810^{-6} \pm 3.510^{-6}$ & \\
\hline & $0.9626 / 6$ & $0.9912 / 11$ & 7.37 \\
\hline
\end{tabular}

* the detection limit was calculated as the ratio between the $3 \mathrm{~S}_{\mathrm{a}} / \mathrm{b}$ where: $\mathrm{S}_{\mathrm{a}}$ is the standard deviation of the intercept of the linear regression, and $b$ is the slope of the linear regression $\left(I=a+b\left[\mathrm{H}_{2} \mathrm{O}_{2}\right]\right)$, when the signal/noise ratio is 3 . 
sed from Fluka (Germany). Hydrogen peroxide (30\% $\mathrm{H}_{2} \mathrm{O}_{2}$ ) (Merck, Germany) was used for daily preparing of $0.01 \mathrm{M}$ standard solutions.

The supporting electrolyte was a $1 / 15 \mathrm{M}$ phosphate buffer $(\mathrm{pH}$ 7) prepared by dissolving the appropriate amounts of $\mathrm{Na}_{2} \mathrm{HPO}_{4} \cdot 12 \mathrm{H}_{2} \mathrm{O}$ (Reactivul-Bucuresti, Romania) and $\mathrm{KH}_{2} \mathrm{PO}_{4}$ (Sigma, Germany) in distilled water. The $\mathrm{pH}$ of the buffer solutions was adjusted to the desired values by adding $\mathrm{H}_{3} \mathrm{PO}_{4}$ or $\mathrm{KOH}$ solutions (Merck, Germany).

All reagents were of analytical degree and were used without further purification. Distilled water was used for preparing all solutions.

\section{2. Preparation of the CPE and CPE-RuNP Electrodes}

Unmodified carbon paste (CPE) was prepared by mixing $0.04 \mathrm{~g}$ of graphite powder with $0.02 \mathrm{ml}$ of paraffin oil. The RuNP modified carbon paste electrodes (CPE-RuNP) were prepared by thoroughly mixing 0.04 $\mathrm{g}$ of graphite powder, $0.02 \mathrm{ml}$ of paraffin oil and $0.02 \mathrm{~g}$ RuNP, (CPE-RuNP (2.5:1)), 0.04 g RuNP (CPE-RuNP (2.5:2)) or, 0.06 g carbon supported RuNP (CPE-RuNP (2.5:3)), respectively. The un/modified carbon paste was placed into a $3 \mathrm{~mm}$ diameter cavity of a Teflon tip (geometric surface area of $0.07 \mathrm{~cm}^{2}$ ), the electric contact being assured by a copper piece placed on the holder surface.

The obtained electrode surface was smoothed manually using a clean filter paper. When necessary, a new electrode surface was obtained by removing a $2 \mathrm{~mm}$ thick layer from the outer paste layer, or adding freshly modified paste.

\section{3. Characterization Methods}

For the electron microscopic illustration of the carbon supported RuNP, a transmission electron microscopy TEM was used (Hitachi Automatic TEM H7650, accelerating voltage $40-120 \mathrm{kV}$, zoom $200 \times-600000 \times$ ).

All electrochemical measurements (cyclic voltammetry and amperometry) were performed using a PC controlled electrochemical analyzer (AUTOLAB PGSTAT302N EcoChemie, Utrecht, Netherlands) into a conventional undivided three-electrodes cell equipped with a $\mathrm{Pt}$ wire, as counter electrode, and a $\mathrm{Ag} / \mathrm{AgCl}, \mathrm{KCl}_{\text {sat }}$ reference electrode. As working electrode the above described tip containing un/modified carbon paste (CPE, CPE -RuNP (w:w)) was fixed on an immobile holder (for unstirred cyclic voltammetry experiments) or on a rotating disc electrode holder (EDI-10K, Radiometer Analytical, France) for controlling the stirring rate of the solution in amperometric experiments.

Batch amperometric measurements were carried out at an applied potential of $-0.1 \mathrm{~V} v s . \mathrm{Ag} / \mathrm{AgCl}, \mathrm{KCl}_{\text {sat }}$ by addition of increasing volumes of $0.01 \mathrm{M} \mathrm{H}_{2} \mathrm{O}_{2}$ solution into a 1/15 $\mathrm{M}$ phosphate buffer ( $\mathrm{pH} 7$ ).

All experiments were carried out in aerated solution at ambient temperature.

\section{Conclusions}

A new carbon paste electrode (CPE) incorporating carbon supported $\mathrm{Ru}$ nanoparticles (RuNP) for $\mathrm{H}_{2} \mathrm{O}_{2}$ amperometric detection was developed and characterized.

The investigation by electrochemical methods of the CPE-RuNP modified electrodes reveals the formation of the $\mathrm{Ru}$ oxides at $+1.0 \div+1.1 \mathrm{~V}$ vs. $\mathrm{Ag} / \mathrm{AgCl}, \mathrm{KCl}_{\text {sat }}$ and the reduction of oxygen at $-0.5 \mathrm{~V} v s . \mathrm{Ag} / \mathrm{AgCl}, \mathrm{KCl}_{\text {sat }}$, value much more positive than those obtained in the absence of RuNP as electrocatalyst. The reduction current of the oxygen is much higher than in the case of the unmodified electrode and is dependent on the scan rate, proving the diffusion control of the redox process involved at the electrode surface.

The relative increase of the $\mathrm{H}_{2} \mathrm{O}_{2}$ reduction current at CPE-RuNP electrodes was evaluated from cyclic voltammetry measurements at $-0.1 \mathrm{~V} v s$. $\mathrm{Ag} / \mathrm{AgCl}, \mathrm{KCl}_{\text {sat }}$, and it varies in the range: $28.47 \%$ (CPE) $<94.81 \%$ (CPE-RuNP $(2.5: 1))<118.19 \%$ (CPE-RuNP $(2.5: 3))<152.43 \%$ (CPE-RuNP (2.5:2)), recommending the new electrode as a promising sensor for hydrogen peroxide detection.

\section{Acknowledgments}

The authors are grateful to Prof. D. Goia (Clarkson University, USA) for the kind gift of RuNP and to Dr. G. Katona (Babes-Bolyai University, Romania) for performing the TEM measurements.

\section{References}

1. K. S. Byadagi, S. T. Nandibewoor and S. A. Chimatadar, Acta Chim. Slov. 2013, 60, 617-627.

2. H. Ma, Ch. Liu, J. Liao, X. Xue and W. Xing, J. Mol. Cat. A: Chem. 2006, 247, 7-13.

http://dx.doi.org/10.1016/j.molcata.2005.11.013

3. N. Mamaca, E. Mayousse, S. Arrii-Clacens, T.W. Napporn, K. Servat, N. Guillet and K.B. Kokoh, Appl. Catal. B: Environ. 2012, 111-112, 376-380.

http://dx.doi.org/10.1016/j.apcatb.2011.10.020

4. N. M. Kiele, C. Herrero, A. Ranjbari, A. Aukauloo, S. A. Grogoriev, A. Villagra, and P. Millet, Int. J. Hydrogen Energ. 2013, 38, 8590-8596.

http://dx.doi.org/10.1016/j.ijhydene.2012.11.012

5. M. Carmo, D. L. Fritz, J. Mergel and D. Stolten, Int. J. Hydrogen Energ. 2013, 38, 4901-4934.

http://dx.doi.org/10.1016/j.ijhydene.2013.01.151 
6. H. Inoue, S. R. Brankovic, J. X. Wang and R. R. Adzic, Electrochim. Acta 2002, 47, 3777-3785.

http://dx.doi.org/10.1016/S0013-4686(02)00348-1

7. J. Prakash and H. Joachin, Electrochim. Acta 2000, 45, 2289-2296. http://dx.doi.org/10.1016/S0013-4686(99)00439-9

8. E.-S. M. Sherif, J. H. Potgieter, J. D. Comins, L. Cornish, P. A. Olubambi and C. N. Machio, Corros. Sci. 2009, 51, 1364-1371.

http://dx.doi.org/10.1016/j.corsci.2009.03.022

9. J. H. Potgieter, N. Thanjekwayo, P. Olubambi, N. Maledi, S. S. Potgieter-Vermaak, Int. J. Refract. Met. H., 2011, 29, 478-487. http://dx.doi.org/10.1016/j.ijrmhm.2011.02.007

10. R. M. A. Tehrani and S. Ab Ghani, Biosens. Biolectron. 2012, 38, 278-283. http://dx.doi.org/10.1016/j.bios.2012.05.044

11. P. Shakktivel and S.-M. Chen, Biosens. Biolectron. 2007, 22, 1680-1687. http://dx.doi.org/10.1016/j.bios.2006.07.026

12. M. Roushani, E. Karami, A. Salami, R. Sahraei, Electrochim. Acta 2013, 113, 134-140.

http://dx.doi.org/10.1016/j.electacta.2013.09.069

13. C. Anjalidevi, V. Dharuman, J. S. Narayanan, Sensor. Actuat. B Chem. 2013, 182, 256- 263.

14. M. Somasundrun, K. Kirtikara and M. Tanticharoen, Anal. Chim. Acta 1996, 319, 59-70. http://dx.doi.org/10.1016/0003-2670(95)00473-4

15. J. Wang, Electroanal. 2001, 13, 983-988. http://dx.doi.org/10.1002/1521-4109(200108)13:12<983:: AID-ELAN983>3.0.CO;2-\#

16. J. Soukup, V. Polan, P. Kotzian, K. Kalcher and K. Vytøas, Int. J. Electrochem. Sci. 2011, 6, 231 - 239.
17. S. B. Hall, E. A. Khudaish and A. L. Hart, Electrochim. Acta, 1998, 43, 2015-2024. http://dx.doi.org/10.1016/S0013-4686(97)10116-5

18. W. Chen, S. Cai, Q.-Q. Ren, W. Wen and Y.- D. Zhao, Analyst 2012, 137, 49-58. http://dx.doi.org/10.1039/C1AN15738H

19. D. Michell, D. A. J. Rand and R. Woods, J. Electroanal. Chem. Interfacial Electrochem. 1978, 89, 11-27. http://dx.doi.org/10.1016/S0022-0728(78)80027-8

20. R. O. Lezna, N. R. De Tacconi and A. J. Arvía, J. Electroanal. Chem. Interfacial Electrochem. 1983, 151, 193-207. http://dx.doi.org/10.1016/S0022-0728(83)80433-1

21. L. D. Burke and J. K. Mulcahy, J. Electroanal. Chem. Interfacial Electrochem. 1976, 73, 207-218. http://dx.doi.org/10.1016/S0022-0728(76)80224-0

22. C. C. Hu, H. R. Chiang and C. C. Wang, J. Solid State Electrochem. 2003, 7, 477-484. http://dx.doi.org/10.1007/s10008-003-0351-6

23. M. Metikos-Hukovic, R. Babic, F. Jovic and Z. Grubac, Electrochim. Acta 2006, 51, 1157-1164. http://dx.doi.org/10.1016/j.electacta.2005.05.029

24. I. Cakar, K. V. Özdokur, B. Demir, E. Yavuz, D. O. Demirkol, S. Kocak, S. Timur and F. N. Ertas, Sens. Actuat. B Chem. 2013, 185, 331-336. http://dx.doi.org/10.1016/j.snb.2013.04.106

25. W. Jia, M. Guo, Z. Zheng, T. Yu, E. G. Rodriguez, Y. Wang and Yu. Lei, J. Electroanal. Chem. 2009, 625, 27-32. http://dx.doi.org/10.1016/j.jelechem.2008.09.020

26. M. Roushani, E. Karami, A. Salimi and R. Sahraei, Electrochim. Acta 2013, 113, 134-140. http://dx.doi.org/10.1016/j.electacta.2013.09.069

27. T. K. Sau, M. Lopez and D. V. Goia, Chem. Mater. 2009, 21, 3649-3654. http://dx.doi.org/10.1021/cm9010629

\section{Povzetek}

$\mathrm{Za}$ amperometrično detekcijo $\mathrm{H}_{2} \mathrm{O}_{2}$ smo razvili novo ogljikovo elektrodo (CPE), stabilizirano z vgrajenimi Ru nanodelci (RuNP). Njene elektrokemične lastnosti smo preverili z meritvami ciklične voltametrije, izveden $\mathrm{v}$ fosftanem pufru napram $\mathrm{Ag} / \mathrm{AgCl}, \mathrm{KCl}_{\text {sat }}$ elektrodi pri različnih spremembah hitrosti in območja potenciala. Pri napetosti $-0.1 \mathrm{~V}$ napram $\mathrm{Ag} / \mathrm{AgCl}, \mathrm{KCl}_{\text {sat }}$, relativni porast redukcijskega toka $\mathrm{za}_{2} \mathrm{O}_{2}$ sledi v naslednjem zaporedju: $28.47 \%(\mathrm{CPE})<94.81 \%$ $($ CPE-RuNP $(2.5: 1))<118.19 \%$ (CPE-RuNP (2.5:3)) < 152.43\% (CPE-RuNP (2.5:2). Dobljene vrednosti kažejo, da nova elektroda predstavlja obetajoč senzor za detekcijo peroksida. 